\title{
Genetic Divergence for Fibre Yield and its Contributing Traits in Roselle (Hibiscus sabdariffa L.)
}

\author{
P. Kranthi Priya*, N. Hari Satyanarayana, Y. Rajasekhar and T. Haritha \\ Dept. of Genetics and Plant Breeding, Agricultural College, \\ Bapatla, Guntur Dist., A. P. - 522 101, India \\ *Corresponding author
}

Keywords

Cluster distance, Genetic divergence, Roselle

Article Info

Accepted:

26 May 2020

Available Online:

10 June 2020
A B S T R A C T

A trail was conducted with 52 genotypes of roselle (Hibiscus sabdariffa L.) at Agricultural Research Station, Amadalavalasa, Srikakulam district for eleven fibre yield and yield contributing characters during kharif 2018-19. All genotypes were gouped into 15 clusters based on $\mathrm{D}^{2}$ analysis. Cluster I comprised of 23 genotypes followed by cluster II with 16 genotypes and cluster III to $\mathrm{XV}$ having solitary genotype. Inter cluster distance was highest between the clusters XIV and XV followed by clusters X and XV, clusters XII and XIII and cluster XIII and XV. Cluster XIV recorded high mean values for plant height, base diameter, mid diameter, petiole length, green fresh weight per plant and dry stick weight per plant whereas cluster $\mathrm{XV}$ recorded low mean values for most of the fibre contributing traits. Green fresh weight per plant contributed high for the diversity value followed by fibre wood ratio, dry stick weight per plant and base diameter. From the studies it can be suggested that the genotypes belonging to cluster X, XII, XIII and XIV could be selected as parents in future hybridization programmes for developing high yielding cultivars in roselle.

\section{Introduction}

Roselle (Hibiscus sabdariffa L.) is an annual erect, bushy, herbaceous shrub grown as annual or biennial plant belonging to family Malvaceae. It is a self pollinated crop with chromosome number, $2 \mathrm{n}=4 \mathrm{x}=72$ mostly cultivated in tropical and sub-tropical regions for bast fibre, paper pulp or edible calyces, leaves and seeds (Sabiel et al., 2014; Osman et al., 2011). It is commonly known by different names in different countries namely Roselle, Karkade, Razelle, Sorrel, Red Sorrel, Jamaica Sorrel, Indian Sorrel, Guinea, Sorrel, Sour -Sour, and Queens Land Jelly plant (Naim and Ahmed, 2010; Mahadevan et al., 
2009). Roselle is one of the important and popular medicinal plant having several properties. The fresh calyces are filled with greater amount of ascorbic acid and also rich in riboflavin, niacin, carotene, calcium and iron while dry calyces contains antimicrobial as well as antioxidant activities due to its phenolic compounds. flavonoids, gossypetine, hibiciscetine and saddaretine. Seeds of roselle have been found to be a good source of protein (Anokwuruet al., 2011).

The success of any crop improvement programme essentially depends on the nature and magnitude of genetic variability present in the crop. Improvement in yield is normally attained through exploitation of the genetically diverse parents for getting good hybrids. In this context Mahalanobis $\mathrm{D}^{2}$ statistic is an effective tool in quantifying the degree of divergence at genetic level and also provides quantitative measure of association between geographic and genetic diversity based on generalized distance (Mahalanobis, 1936). The present study was carried out to ascertain the nature and magnitude of genetic divergence among 52rosellegenotypes.

\section{Materials and Methods}

The experiment material for genetic divergence studies comprised of 52 genotypes of roselle belonging to different regions of India. The material under study was made available at Agriculture Research Station, Amadalavalasa (Andhra Pradesh) through AINPJAF, CRIJAF and Kolkata. The experiment was laid out in Randomized Block Design with three replications during kharif2018-19. Each genotype was sown in single row of $4.5 \mathrm{~m}$ length with a spacing of $40 \times 10 \mathrm{~cm}$. The data was collected from 5 randomly selected plants in a row for each replication. All the fibre yield parameters were recorded at the time of harvesting. Fibre was extracted by standard method of retting.

Data was recorded for 11 quantitative characters viz., days to $50 \%$ flowering, plant height, base diameter, mid diameter, petiole length, number of nodes per plant, internode length, green fresh weight per plant, dry stick weight per plant, fibre wood ratio and dry fibre yield per plant. Mahalanobis $\mathrm{D}^{2}$ statistic was used to assess the diversity among genotypes and they were grouped into different Clusters using the Tocher's method as described by Rao (1952) and the genotypes were grouped into different clusters utilizing Tocher's method.

\section{Results and Discussion}

The analysis of variance revealed significant differences among 52 genotypes for all the eleven characters under study which indicated the existence of significant amount of variability among the 52 genotypes for all the characters. On the basis of Mahalanobis $\mathrm{D}^{2}$ analysis, 52 genotypes were grouped into 15 clusters based on 11 fibre yield attributing traits viz., days to $50 \%$ flowering, plant height, base diameter, mid diameter, petiole length, number of nodes per plant, internode length, green fresh weight per plant, dry stick weight per plant, fibre wood ratio and dry fibre yield per plant. The clusters formed were furnished in (Table 1) On the basis of average cluster distance, following Tocher's method considering fibre yield and its contributing characters. The cluster I comprised of 23 genotypes followed by cluster II with 16 genotypes and Cluster III to XV having solitary genotype. Similar results were reported by earlier reports of Anuradha (2003) and Pullibai et al., (2005).

The results obtained through classification of genotypes using $\mathrm{D}^{2}$ statistics would provide a set of groups from which desirable parents may be selected for further breeding programme with respect to fibre yield attributing characters. By considering the $\mathrm{D}^{2}$ values presented in (Table 2) it was noticed the values varied from 6.86 to 1901.83 . 
Table.1 Clustering of genotypes by Tochers method

\begin{tabular}{|c|c|c|c|}
\hline $\begin{array}{l}\text { Cluster } \\
\text { number }\end{array}$ & $\begin{array}{l}\text { Number of } \\
\text { genotypes }\end{array}$ & Genotypes & Origin \\
\hline I & 23 & 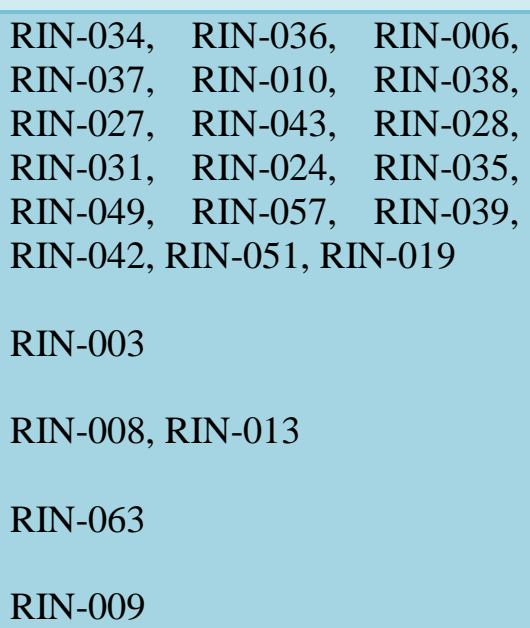 & $\begin{array}{l}\text { Andhra Pradesh(1) } \\
\text { Delhi (2) } \\
\text { Orissa (1) } \\
\text { Assam (1) }\end{array}$ \\
\hline II & 16 & $\begin{array}{l}\text { RIN-047, RIN-055, RIN-060, } \\
\text { RIN-054, RIN-053, RIN-021, } \\
\text { RIN-030, RIN-011, RIN-044, } \\
\text { RIN-056 } \\
\text { RIN-012, RIN-040, RIN-016 } \\
\text { RIN-014 } \\
\text { RIN-061, AMV-5 }\end{array}$ & $\begin{array}{l}\text { West Bengal (10) } \\
\text { Delhi (3) } \\
\text { Madhya Pradesh (1) } \\
\text { Andhra Pradesh (2) }\end{array}$ \\
\hline III & 1 & RIN-025 & West Bengal (1) \\
\hline IV & 1 & RIN-046 & West Bengal (1) \\
\hline $\mathbf{V}$ & 1 & RIN-045 & West Bengal (1) \\
\hline VI & 1 & RIN-007 & West Bengal (1) \\
\hline VII & 1 & RIN-052 & West Bengal (1) \\
\hline VIII & 1 & RIN-015 & Delhi (1) \\
\hline IX & 1 & RIN-059 & West Bengal (1) \\
\hline $\mathbf{X}$ & 1 & RIN-050 & West Bengal (1) \\
\hline XI & 1 & HS-4288 & West Bengal (1) \\
\hline XII & 1 & RIN-020 & West Bengal (1) \\
\hline XIII & 1 & RIN-026 & West Bengal (1) \\
\hline XIV & 1 & RIN-018 & West Bengal (1) \\
\hline $\mathbf{X V}$ & 1 & RIN-032 & West Bengal (1) \\
\hline
\end{tabular}


Table.2 Inter and intra cluster $\mathrm{D}^{2}$ values of 52 genotypes of roselle - Tocher's method

\begin{tabular}{|c|c|c|c|c|c|c|c|c|c|c|c|c|c|c|c|}
\hline Cluster & I & II & III & IV & V & VI & VII & VIII & IX & $\mathbf{X}$ & XI & XII & XIII & XIV & $\mathbf{X V}$ \\
\hline I & 21.53 & 78.15 & 48.30 & 60.68 & 64.16 & 278.22 & 75.34 & 167.96 & 158.51 & 112.36 & 64.48 & 426.84 & 226.50 & 118.59 & 447.75 \\
\hline II & & 48.86 & 140.42 & 220.52 & 172.40 & 127.46 & 81.54 & 150.06 & 80.10 & 533.15 & 105.27 & 139.48 & 696.43 & 436.39 & 214.62 \\
\hline III & & & 0.00 & 189.89 & 6.86 & 107.54 & 44.22 & 121.00 & 452.41 & 87.05 & 258.57 & 379.86 & 154.26 & 142.56 & 1012.51 \\
\hline IV & & & & 0.00 & 214.33 & 690.11 & 314.00 & 536.39 & 296.87 & 67.90 & 34.69 & 773.40 & 55.20 & 208.80 & 337.46 \\
\hline $\mathbf{V}$ & & & & & 0.00 & 201.07 & 14.98 & 76.56 & 506.70 & 50.69 & 330.15 & 334.89 & 166.41 & 112.36 & 1101.58 \\
\hline VI & & & & & & 0.00 & 113.21 & 292.07 & 487.97 & 1102.90 & 580.81 & 55.50 & 1158.72 & 1016.33 & 489.29 \\
\hline VII & & & & & & & 0.00 & 75.34 & 295.50 & 231.34 & 277.22 & 100.60 & 448.59 & 180.10 & 771.73 \\
\hline VIII & & & & & & & & 0.00 & 137.36 & 477.42 & 329.79 & 226.50 & 631.52 & 300.68 & 715.56 \\
\hline IX & & & & & & & & & 0.00 & 940.65 & 49.56 & 258.89 & 1071.25 & 480.05 & 127.01 \\
\hline $\mathbf{X}$ & & & & & & & & & & 0.00 & 268.30 & 1365.30 & 24.90 & 84.82 & 1812.20 \\
\hline XI & & & & & & & & & & & 0.00 & 437.23 & 398.40 & 200.51 & 302.76 \\
\hline XII & & & & & & & & & & & & 0.00 & 1467.66 & 1062.76 & 406.62 \\
\hline XIII & & & & & & & & & & & & & 0.00 & 287.98 & 1402.50 \\
\hline XIV & & & & & & & & & & & & & & 0.00 & 1901.83 \\
\hline XV & & & & & & & & & & & & & & & 0.00 \\
\hline
\end{tabular}


Table.3 Cluster means for eleven characters in 52 genotypes of roselle

\begin{tabular}{|c|c|c|c|c|c|c|c|c|c|c|c|}
\hline Clusters & $\begin{array}{c}\text { Days to } \\
50 \% \\
\text { flowering }\end{array}$ & $\begin{array}{c}\text { Plant } \\
\text { height } \\
\text { (cm) }\end{array}$ & $\begin{array}{c}\text { Base } \\
\text { diameter } \\
(\mathbf{m m})\end{array}$ & $\begin{array}{c}\text { Mid } \\
\text { diameter } \\
(\mathbf{m m})\end{array}$ & $\begin{array}{c}\text { Petiole } \\
\text { length } \\
(\mathrm{cm})\end{array}$ & $\begin{array}{c}\text { Number of } \\
\text { nodes per plant }\end{array}$ & $\begin{array}{l}\text { Internode } \\
\text { length }\end{array}$ & $\begin{array}{c}\text { Green plant } \\
\text { weight per } \\
\text { plant (g) }\end{array}$ & $\begin{array}{c}\text { Dry stick } \\
\text { weight per } \\
\text { plant }(g)\end{array}$ & $\begin{array}{l}\text { Fibre } \\
\text { wood } \\
\text { ratio }\end{array}$ & $\begin{array}{c}\text { Fibre yield } \\
\text { per plant } \\
\text { (g) }\end{array}$ \\
\hline $\mathbf{I}$ & 130.55 & 277.08 & 16.22 & 11.67 & 9.76 & 50.95 & 5.61 & 277.13 & 39.63 & 0.38 & 14.92 \\
\hline II & 131.33 & 237.19 & 14.54 & 10.34 & 9.78 & 47.23 & 5.63 & 229.38 & 31.13 & 0.38 & 11.53 \\
\hline III & 129.67 & 288.00 & 16.92 & 12.50 & 10.48 & 57.93 & 5.33 & 338.67 & 38.07 & 0.44 & 16.73 \\
\hline IV & 131.00 & 276.00 & 15.49 & 11.30 & 9.73 & 47.13 & 6.35 & 236.67 & 37.20 & 0.49 & 17.73 \\
\hline $\mathbf{V}$ & 132.00 & 257.67 & 17.13 & 11.75 & 10.03 & 52.67 & 4.83 & 358.67 & 41.40 & 0.43 & 17.27 \\
\hline VI & 129.67 & 232.33 & 14.37 & 10.33 & 9.37 & 50.00 & 5.12 & 212.67 & 20.67 & 0.48 & 10.00 \\
\hline VII & 132.00 & 209.00 & 16.99 & 11.42 & 10.50 & 45.67 & 4.77 & 294.67 & 36.87 & 0.39 & 14.00 \\
\hline VIII & 130.33 & 224.00 & 15.13 & 9.43 & 10.27 & 49.33 & 5.20 & 352.00 & 43.00 & 0.34 & 14.67 \\
\hline IX & 131.33 & 221.67 & 12.72 & 9.74 & 9.35 & 45.27 & 6.46 & 246.67 & 38.60 & 0.29 & 10.87 \\
\hline $\mathbf{X}$ & 131.67 & 295.67 & 18.34 & 12.86 & 10.07 & 53.13 & 5.70 & 373.33 & 47.53 & 0.47 & 21.67 \\
\hline XI & 132.00 & 276.33 & 15.15 & 10.92 & 10.15 & 45.47 & 7.30 & 256.67 & 38.13 & 0.37 & 14.00 \\
\hline XII & 132.33 & 171.67 & 13.00 & 9.17 & 9.73 & 36.40 & 5.53 & 226.67 & 21.07 & 0.47 & 9.87 \\
\hline XIII & 129.33 & 267.67 & 16.72 & 12.43 & 10.95 & 54.13 & 5.77 & 326.67 & 41.87 & 0.57 & 23.53 \\
\hline XIV & 131.00 & 298.00 & 18.35 & 13.84 & 11.07 & 49.47 & 5.97 & 401.33 & 58.27 & 0.31 & 17.73 \\
\hline $\mathbf{X V}$ & 131.67 & 196.67 & 10.46 & 7.73 & 8.42 & 42.33 & 5.67 & 92.00 & 21.40 & 0.45 & 9.67 \\
\hline
\end{tabular}


Table.4 Relative contribution of 11 characters towards divergence in roselle (Hibiscus sabdariffaL.)

\begin{tabular}{|c|l|c|c|}
\hline S.no & \multicolumn{1}{|c|}{ Character } & Times ranked & Contribution \% \\
\hline $\mathbf{1}$ & Days to 50\% flowering & 27 & $2.04 \%$ \\
\hline $\mathbf{2}$ & Plant height & 109 & $8.22 \%$ \\
\hline $\mathbf{3}$ & Base diameter & 115 & $8.67 \%$ \\
\hline $\mathbf{4}$ & Mid diameter & 20 & $1.51 \%$ \\
\hline $\mathbf{5}$ & Petiole length & 5 & $0.38 \%$ \\
\hline $\mathbf{6}$ & Number of nodes /plant & 25 & $1.88 \%$ \\
\hline $\mathbf{7}$ & Internode length & 107 & $8.07 \%$ \\
\hline $\mathbf{8}$ & Green fresh weight/plant & 321 & $24.21 \%$ \\
\hline $\mathbf{9}$ & Dry stick weight/plant & 180 & $13.57 \%$ \\
\hline $\mathbf{1 0}$ & Fibre wood ratio & 314 & $23.68 \%$ \\
\hline $\mathbf{1 1}$ & Fibre yield /plant & 103 & $7.77 \%$ \\
\hline & Total & $\mathbf{1 3 2 6}$ & $\mathbf{1 0 0 \%}$ \\
\hline
\end{tabular}

The maximum inter cluster distance was observed between cluster XIV and XV (1901.38) followed by cluster $X$ and XV (1812.20), cluster XII and XIII (1467.66) and cluster XIII and XV (1402.50) indicating wider genetic diversity. The intra cluster $\mathrm{D}^{2}$ values ranged from zero (cluster III to $\mathrm{XV}$ ) to 48.86 (cluster II). Wider genetic diversity was evident among the genotypes belonging to different clusters than those with the same cluster. The highest inter cluster distance between cluster XIV with XV followed by cluster $\mathrm{X}$ and XV, cluster XII and XIII and cluster XIII and XV indicate that the genotypes belonging to cluster XIV were widely distanced genetically than those from those of cluster XV, X, XII and XIII. The maximum intra cluster distance varied from 48.16 for cluster II to minimum 21.53 for cluster I with 23 genotypes.

Variations in mean values among different clusters for different characters was observed and presented in (Table 3). Among 11 characters studied, Cluster XIV has highest mean for plant height, base diameter, mid diameter, petiole length, green fresh weight per plant and dry stick weight per plant; whereas Cluster XIII recorded highest mean for fibre wood ratio and fibre yield per plant and cluster XI for high internode length. Percent contribution of individual characters towards total genetic divergence in furnished in (Table 4). Green fresh weight per plant contributed (24.21\%) towards genetic divergence followed by fibre wood ratio $(23.68 \%)$, dry stick weight per plant $(13.57$ $\%)$, base diameter $(8.67 \%)$, plant height $(8.22$ $\%)$, internode length $(8.07 \%)$, fibre yield per plant $(7.77 \%)$, days to $50 \%$ flowering $(2.04$ $\%)$, number of nodes per plant $(1.88 \%)$, mid diameter $(1.51 \%)$, petiole length $(0.38$ $\%)$.Similar results were reported by Satyanarayana et al., (2013), Pullibai et al., (2005). Among the 11 quantitative characters studied, seven characters viz., green fresh weight per plant, fibre wood ratio, dry stick weight per plant, base diameter, plant height, internode length, and fibre yield per plant contributed $94.19 \%$ towards divergence, whereas the rest of the characters contributed for $5.82 \%$ to the total divergence. Similar results were reported by Kumar et al., (2013) and Satyanarayana et al., (2015) and Jyotsna and Satyanarayana (2016) 
In conclusion, considering the results obtained from cluster distances and mean values, the genotypes belonging to cluster $\mathrm{X}$ (RIN-050), XII (RIN-020), XIII (RIN-026), XIV (RIN-018) were found highly diverse and may serve as potential parents for future hybridization programmes.

\section{References}

Anokwuru C P, Esiaba I, AjibayeandAdessuyi A O. 2011.Polyphenolic content and antioxidant activity of Hibiscus sabdariffa calyx. Research Journal of Medicinal Plant. 5: 557-566.

Anuradha T. 2003.Genetic divergence in roselle (Hibiscus sabdariffa L.). Journal of Research ANGRAU. 31 (2): 122-126.

Jyotsna $\mathrm{S}$ and Satyanarayana $\mathrm{N} \mathrm{H}$. 2016.Genetic divergence studies for fibre yield and its contributing traits in roselle (Hibiscus sabdariffaL.). Vegetos. 29 (3): 1-2.

Kumar B H R and Appalaswamy A, Prasad A V S D and Ismail S.2013. Genetic divergence studies in roselle (Hibiscus sabdariffa L.). Madras Agricultural Journal. 100(1-3):20-22

Mahadevan N, Shivali and Pradeep, K. 2009. Hibiscus sabdariffa Linn: An overview. Natural Product Radiance. 8: 77-83.

Mahalanobis P C. 1936.On the generalized distance in statistics. Proceeding of National Institute of Science.2: 49-55.

Naim El A M and Ahmed S E. 2010. Effect of weeding frequencies on growth and yield of two roselle (Hibiscus sabdariffa
L) varieties under rain fed. Australian Journal of Basic and Applied Sciences. 4(9): 4250 - 4255.

Osman M, Faruq G, Saberi S, Majid N A, Nagoor, N.H and Zulqarnain M. 2011. Morpho-agronomic analysis of three roselle (Hibiscus sabdariffa L.) mutants in tropical Malaysia. Australian Journal of Crop Sciences. 5 (10): 1150-1156.

Pullibai P, Sultana R, Rao C P and Rao V S. 2005.Multivariate analysis in roselle hemp (Hibiscus sabdariffa L). The Andhra Agricultural Journal. 52 (1\&2): 86-92.

Rao C R. 1952.Advanced Statistical Methods in Biometrical Research. John Wiley and Sons Inc., New York. Pp. 236-272.

Sabiel S A I, Mohamed II, Osman K A and Dongfa S. 2014. Genetic variability for yield and related attributes of roselle (Hibiscus sabdariffa L.) genotypes under rain-fed conditions in a semi-arid zone of Sudan. Persian Gulf Crop Protection.3 (1): 33-40.

Satyanarayana N H, Kumar, V M andVisalakshmi.2013. Genetic diversity in roselle. Crop Improvement. 40 (1): 95-97.

Satyanarayana N H, Mukherjee S, Roy S, Bhanupriya, Sarkar K K and Bandhopadhyay P. 2015. Genetic divergence studies for fibre yield traits in roselle (Hibiscus sabdariffa L.) in terai zone of West Bengal. Journal of Crop and Weed. 11: 90-94.

\section{How to cite this article:}

Kranthi Priya, P., N. Hari Satyanarayana, Y. Rajasekhar and Haritha, T. 2020. Genetic Divergence for Fibre Yield and its Contributing Traits in Roselle (Hibiscus sabdariffa L.). Int.J.Curr.Microbiol.App.Sci. 9(06): 3639-3645. doi: https://doi.org/10.20546/ijcmas.2020.906.428 